\title{
ВПЛИВ ПОЛІПШУВАЛЬНОЇ ПОРОДИ НА МОЛОЧНУ ПРОДУКТИВНІСТЬ КОРІВ РІЗНИХ ПОРІД ВІТЧИЗНЯНОЇ СЕЛЕКЦІЇ
}

\author{
Войтенко Світлана Леонідівна \\ доктор сільськогосподарських наук, професор \\ Інститут розведення і генетики тварин імені М.В.Зубця НААН України \\ ORCID: https://orcid.org/0000-0002-7196-8700 \\ Email: slvoitenko@ukr.net
}

Сидоренко Олена Василівна кандидат сільськогосподарських наук, старший науковий співробітник Інститут розведення і генетики тварин імені М.В.Зубця НААН України ORCID: https://orcid.org/0000-0003-2429-9361

Email: sydorenkoolena@ukr.net

\begin{abstract}
Селекиія великої рогатої худоби молочного напряму продуктивності в Україні останні роки здійснюється за інтенсивного використання відтворного схрещування, де батьківською породою є голштинська, що приводить до появи в стаді чи породі особин з величезною різноманітністю генотипів з неоднорідною продуктивністю. Для консолідації великої рогатої худоби українських молочних порід за господарськи корисними ознаками необхідно встановлювати гранично допустимі межі умовної кровності голштинської породи в генотипі тварин новостворених порід. Метою досліджень було визначення молочної продуктивності корів різних порід племінних стад дослідних господарств мережі НААН у залежності від умовної частки кровності в їх генотипі голштинської породи. Дослідження проведені у стадах дослідних господарствах мережі НААН за даними племінного обліку корів української чорно-рябої молочної породи (2130 голів), української червоно-рябої молочної породи (689 голів) і української червоної молочної породи (176 голів). Встановлена значна диференціація надоїв корів різних порід у залежності від частки умовної кровності за голштинською породою. Доведена можливість рівномірного підвищення молочної продуктивності корів української червоної молочної породи першої і вищої лактації із зростанням частки кровності за голштинською породою. Для корів української червоно-рябої молочної породи верхня межа умовної кровності за голштинською породою, яка сприяла підвищенню надою першої лактації становила 87,49 \%, а за вищою лактацією - 75,0 \%. Тварини української чорно-рябої молочної породи встановлено вищий надій першої і вищої лактації із збільшенням в їх генотипі умовної частки кровності за поліпшувальною породою до 75,0%. Збільшення частки умовної кровності за голштинською породою понад вказані межі приводить до зниження молочної продуктивності корів. Загалом, подальше розведення худоби українських молочних порід потребує чіткого обгрунтування використання голштинської породи для відтворювального схрещування з урахуванням одержаних результатів впливу умовної кровності на молочну продуктивність корів.
\end{abstract}

Ключові слова: велика рогата худоба, молочна продуктивність, лактація, умовна кровність, поліпшувальна поpoda.

DOI: https://doi.org/10.32845/bsnau.Ivst.2019.4.6

Молочна продуктивність корів відноситься до основних селекційних ознак добору і її поліпшення узгоджується з багатьма чинниками, серед яких методи розведення, породні особливості, успадковуваність ознак, генотип батька і матері, їх поєднання, лінійна належність, умови утримання, рівень годівлі, способи доїння, методи обліку показників продуктивності та інші $[16,19,24]$. Серед усіх транскордонних порід великої рогатої худоби молочного та комбінованого молочно-м'ясного напряму продуктивності визнаною рекордисткою за молочною продуктивністю вважається голштинська порода $[5,8,14,22]$. Використання цієї породи при виробництві молока забезпечує високу ефективність та прибутковість галузі $[17,23]$. Проте на думку одних дослідників, високий надій корів цієї породи не завжди узгоджується з рештою господарськи корисними ознаками, такими як відтворна здатність, екстер'єр, тривалість господарського використання помісних корів тощо [15, 17], хоча вони частково нівелюються молочною продуктивністю худоби і не стають на заваді інтенсивного використання голштинської породи при схрещуванні. Інші вчені, навпаки, доводять ефективність схрещування тварин різних порід з голштинською, особливо за ознаками довічного використання і відтворення $[7,11]$. Різні точки зору науковців щодо використання цієї породи при схрещуванні та створенні нових порід слугують приводом для подальшого вивчення її ролі у породоутворюючому процесі.

Селекція великої рогатої худоби молочного напряму продуктивності в Україні останні роки здійснюеться за інтенсивного використання відтворного схрещування, де батьківською породою $є$ голштинська, що приводить до появи в стаді чи породі особин з високою генетичною мінливістю та неоднорідною за продуктивністю. Для створення стад чи порід, тварини в яких були б вирівняні та фенотипово подібні за більшістю ознак продуктивності, необхідно, в числі інших, проводити моніторинг впливу умовної частки кровності поліпшувальної породи, оскільки постійне використання голштинської породи для відтворення маточного поголів'я українських молочних порід великої рогатої худоби вже можна класифікувати як поглинальне схрещування.

Україна з середини минулого століття для поліпшення місцевої худоби почала інтенсивно використовувати відтворне схрещування, де в якості поліпшувальної породи використовували голштинську, що сприяло створенню популяцій з високим генетичним потенціалом за основними селекційними ознаками продуктивності [4]. Програмами їх створення вбачалося в генотипі худоби мати певну частку 
умовної кровності за голштинською породою і зберігати її на рекомендованому рівні $[3,10,12,13]$. Але аналіз поголів'я корів племінних стад різних порід засвідчив відхилення від запрограмованої частки умовної кровності за голштинською породою за відсутності єдиної точки зору серед дослідників щодо її величини [3]. При цьому одні науковці переконують, що надій корів обумовлюється адитивним характером успадкування і чим вища умовна частка кровності поліпшувальної породи, тим її продуктивність вища $[9,25]$. Інші, навпаки, доводить, що висококровні за голштинською породою корови мають нижчу продуктивність, порівняно з тими, що мають в своєму генотипі 50-75 \% кровності даної породи $[1,18,21]$. Існує також бачення, що селекція сучасних українських порід молочної худоби повинна узгоджуватися не 3 генотипом тварин, тобто умовною кровністю за вихідними породами, а породним типом [ 6, 20]. 3 огляду на зазначене, останні роки науковці почали відходити від вирішення проблеми взаємозв'язку молочної продуктивності корів різних порід з умовною часткою кровності поліпшувальної породи, що відображається у незначній кількості наукових праць. Але не дивлячись на подібні тенденції, актуальним все ж залишається питання встановлення гранично допустимих меж кровності голштинської породи в генотипі тварин різних порід та обгрунтування подальшого відтворного схрещування в умовах сучасного виробництва молока.

Метою досліджень було визначення молочної продуктивності корів різних порід племінних стад дослідних господарств мережі НААН у залежності від умовної частки кровності в їх генотипі голштинської породи та обґрунтування подальшого використання відтворного схрещування за участі поліпшувальної породи.

Матеріали та методи дослідженнь. Дослідження проведені у стадах дослідних господарствах мережі НААН: 10 стадах з розведення української чорно-рябої молочної породи (ДП "ДГ "Еліта"МІП ІМ. В.М. Ремесла НААН", ДП "ДГ "Гонтарівка" ІТ НААН", ДП "ДГ "Елітне" КДСГДС НААН", ДП "ДГ "Пасічна" ІК СГП НААН", ДП "ДГ "Нива" ІРГТ ім. М.В.Зубця НААН", ДП "ДГ "ім. 9 Січня" Інституту свинарства і АПВ НААН", ДП "ДГ "Нова Перемога" ІСГ Полісся НААН", ДП "ДГ "Шевченківське" ІБКІЦБ НААН", ДП "ДГ "Асканійське" АДСДС І3З НААН", ДП "ДГ "Олександрівське" ННЦ ІЗ НААН", 2130 голів), 3 стадах - української червоно-рябої молочної породи (ДП "ДГ "Олександрівське" ННЦ ІЗ НААН", ДП
"ДГ "Христинівське" ІРГТ ім. М.В.Зубця НААН", ДП "ДГ "Нива" ІРГТ ім. М.В.Зубця НААН", 689 голів) та одного стада української червоної молочної породи (ДП "ДГ "Елітне" ІСГС НААН", 176 голів).

Для проведення дослідження корів було розділено на 4 групи з умовною часткою кровності за голштинською породою: I - 50,0 \% і менше; II - 50,01-75,00 \%; III - 75,01$87,49 \%$; IV - 87,50 \% і вище.

Для визначення впливу умовної частки кровності голштинської породи використовували матеріали автоматизованого племінного обліку інформаційної бази даних СУМС "Інтесел-Орсек" за 2018 рік. Порівняння різних груп корів здійснювали за надоєм молока за 305 днів першої і вищої лактації.

Опрацювання експериментальних даних проводили методами математичної статистики [9] засобами програмного пакету «Statistika 6.0» на ПК [2].

Результати досліджень. За результатами наших досліджень виявлено залежність надою корів від умовної частки кровності за голштинською породою, причому різну і за окремими групами досить суттєву. Одержані нами дані узгоджуються із дослідженнями багатьох науковців [3, 14, 23], які, перш за все, акцентують увагу на необхідності контролювання ситуації в стадах і породах та дотриманні рекомендацій щодо розведення худоби відповідної умовної кровності за голштинською породою, оскільки повне витіснення спадковості вихідних материнських порід переводить вітчизняні породи в площину голштинської породи.

Встановлено, що серед 176 досліджених корів української червоної молочної породи найбільше особин (103 голови) зараховані до групи висококровних, частка спадковості яких за поліпшувальною породою становила $87,5 \%$ і більше. Для первісток цієї породи встановлена тенденція підвищення надою за 305 днів лактації із збільшенням в їх генотипі умовної частки кровності за голштинською породою. Так, корови першої групи (50 \% і менше кровності за голштинською) за 305 днів першої лактації продукували 5892 кг молока, корови другої групи - 6996 кг, що на 1104 кг більше за тварин першої групи (табл. 1). Первістки третьої групи на 1522 кг і 418 кг перевищували показники ровесниць першої і другої групи, а корови четвертої, відповідно, на 1714 кг, 610 кг і 192 кг - представниць трьох попередніх груп.

Надій корів у залежності від умовної частки кровності за голштинською породою

\begin{tabular}{|c|c|c|c|c|}
\hline \multirow{2}{*}{ Показник } & \multicolumn{4}{|c|}{ Умовна частка кровності за голштинською породою } \\
\hline & $50 \% \mathrm{i}<$ & $50,01-75,00 \%$ & $75,01-87,49 \%$ & $87,5 \% \mathrm{i}>$ \\
\hline \multicolumn{5}{|c|}{ Українська червона молочна порода } \\
\hline Надій першої лактації, кг & $5892 \pm 542,3$ & $6996 \pm 162,9$ & $7414 \pm 200,5$ & $7606 \pm 120,9$ \\
\hline Надій вищої лактації, кг & $8685 \pm 230,3$ & $8200 \pm 222,1$ & $8722 \pm 184,3$ & $8738 \pm 119,9$ \\
\hline \multicolumn{5}{|c|}{ Украӥнська червоно-ряба молочна порода } \\
\hline Надій першої лактації, кг & - & $5780 \pm 130,8^{*}$ & $6309 \pm 52,5$ & $6288 \pm 45,9$ \\
\hline Надій вищої лактації, кг & - & $7151 \pm 111,1$ & $7055 \pm 45,5$ & $6961 \pm 48,4$ \\
\hline \multicolumn{5}{|c|}{ Українська чорно-ряба молочна порода } \\
\hline Надій першої лактації, кг & $5590 \pm 222,7$ & $5794 \pm 1075,3$ & $5386 \pm 1336,0$ & $5653 \pm 1402$ \\
\hline Надій вищої лактації, кг & $6326 \pm 203,9$ & $6555 \pm 1162,0$ & $6182 \pm 1396,2$ & $6337 \pm 1495,1$ \\
\hline
\end{tabular}

Примітка: * - $P>0,95$ за порівняння до найвищого надою в групі.

Причому різниця між помісними тваринами, які у своєму генотипі мали 50 \% і менше умовної частки кровності за голштинською породою і тими, які накопичили в своєму генотипі 87,5 \% і більше умовної кровності за поліпшувальною породою, переконливо свідчить про ефективність поглинання вихідного материнського матеріалу батьківською 
породою. На нашу думку, збільшення кровності за батьківською породою для первісток української червоної молочної породи супроводжується значним підвищенням їх надою за лактацію. Надій корів української червоної молочної породи за вищу лактації різних дослідних груп, за виключенням другої (50,01-75,00 \%), теж збільшувався із підвищенням кровності за голштинською породою.

3-поміж досліджених корів української червоно-рябої молочної породи не виявлено напівкровних особин, або тих, що мали 50 \% і менше кровності за поліпшувальною породою, тому ми аналізували лише продуктивність тварин другої - четвертої груп. Серед 689 досліджених корів цієї породи, які утримують у трьох стадах, найбільш представницькою за чисельністю була четверта група (382 голови), тварини якої віднесені до IV групи - 87,5 \% і більше кровності за голштинською породою. Слід також зауважити, що в стадах української червоно-рябої молочної породи не виявлено високу чисельність помісних тварин, які б своєму генотипі мали 50,01-75,00 \% умовної кровності за голштинською породою, тобто, відбувається поглинання і цього матеріалу, а отже їх кровність підвищується за цією породою. Доведено, що для первісток української червоно-рябої молочної породи витіснення вихідного материнського матеріалу батьківським, зокрема голштинської породи, виявилося ефективним і супроводжувалося підвищенням надою за збільшення кровності у генеотипі від 50,01\% до 87,49 \%. Різниця між коровами української червоно-рябої молочної породи другої та третьої груп за надоєм першої лактації становила 529 кг, підтверджуючи, що підвищення молочної продуктивності із збільшенням кровності за поліпшувальною породою. Одночасно, збільшення кровності за голштинською породою до $87,5 \%$ і більше супроводжується незначним - 21 кг, але зниженням надою у первісток. За даними вищої лактації найбільшу кількість молока одержали від корів української червоно-рябої молочної породи, частка умовної кровності яких за голштинською породою становила 50,01-75,00 \%. Збільшення спадковості голштинської породи в генотипі корів української червоно-рябої молочної породи приводить до зниження надою за вищу лактацію.

Нами встановлено, що серед 2130 досліджених корів української чорно-рябої молочної породи 10 племінних стадах дослідних господарств мережі НААН помісних корів першої генерації становило лише 40 голів за найбільшої кількості (1504 голів) тих, які мають 87,5 \% і більше кровності за голштинською породою. Тобто, для цієї породи, як і для української червоно-рябої молочної, характерне підвищення в генотипі тварин кровності голштинської породи. Доведено, що у первісток української чорно-рябої молочної породи підвищується молочна продуктивність за збільшення частки умовної кровності голштинської породи в їх генотипі до 75 $\%$. Корови з умовною кровністю 50,01-75,0 \% за поліпшувальною породою (II група) характеризувалися найвищим надоєм першої лактації з-поміж інших досліджуваних груп і перевищували надій одностадниць з меншою часткою кровності на 204 кг, а більш висококровних, відповідно, на 408 кг і 141 кг. Продуктивність корів української чорно-рябої молочної породи за вищу лактацію мала подібну тенденцію до корів першої лактації. Тобто, високий надій у корів спостерігаємо до накопичення в їх генотипі $75,0 \%$ кровності за голштинською породою, а подальше її підвищення приводило до зворотної дії.

Враховуючи, що корови досліджених порід лактували в різних умовах утримання і годівлі, а також кліматичної зони, нами визначена мінливість їх молочної продуктивності - показник, що засвідчує можливість поліпшення ознаки методами селекції. За нашими дослідженнями, найбільш варіативними за надоєм були корови української чорнорябої молочної породи, причому не залежно від частки умовної кровності батьківської породи та порядкового номеру лактації (табл. 2). Коефіцієнт мінливості молочної продуктивності корів цієї породи засвідчує ефективність добору в кожній групі за кровністю, що в свою чергу слугуватиме формуванню консолідованої популяції.

Коефіцієнт варіації надоїв корів різних порід у залежності

Таблиця 2 від умовної частки кровності за голштинською породою

\begin{tabular}{|c|c|c|c|c|}
\hline \multirow{2}{*}{ Показники } & \multicolumn{4}{|c|}{ Умовна частка кровності за голштинською породою } \\
\hline & $50 \%$ i $<$ & $50,01-75,00 \%$ & $75,01-87,49 \%$ & $87,5 i>$ \\
\hline \multicolumn{5}{|c|}{ Українська червона молочна порода } \\
\hline Надій першої лактації, кг & 18,4 & 13,2 & 16,4 & 16,1 \\
\hline Надій вищої лактації, кг & 5,3 & 15,3 & 12,9 & 13,9 \\
\hline \multicolumn{5}{|c|}{ Українська червоно-ряба молочна порода } \\
\hline Надій першої лактації, кг & - & 16,9 & 13,2 & 14,2 \\
\hline Надій вищої лактації, кг & - & 11,6 & 10,2 & 13,6 \\
\hline \multicolumn{5}{|c|}{ Українська чорно-ряба молочна порода } \\
\hline Надій першої лактації, кг & 25,2 & 18,6 & 24,8 & 24,8 \\
\hline Надій вищої лактації, кг & 20,4 & 17,7 & 22,6 & 23,6 \\
\hline
\end{tabular}

Корови української червоно-рябої молочної породи та української червоної молочної, характеризувалися меншою мінливістю молочної продуктивності, як у межах досліжених груп, так і популяції в цілому, однією з причин чого може бути не велика кількість стад і досліджених тварин. В результаті чого сформувати однорідну групу тварин за молочною продуктивністю в залежності від спадковості за голштинською породою серед цих досліджених порід буде дещо складніше. Проте для більш об'єктивних суджень слід повторити дослідження на значно більшій популяції тварин.
Висновки з даного дослідження і їхні перспективи у даному напрямку.

Молочна продуктивність корів, зокрема надій первісток, має значну диференціацію у залежності від умовної частки кровності в їх генотипі голштинської породи.

Корови української червоної молочної породи містять ще достатньо інформації вихідних материнських порід, яка при схрещуванні з плідниками голштинської породи забезпечує прояв гетерозису за основними ознаками продуктивності. При цьому надій первісток української червоної мо- 
лочної породи рівномірно збільшувався із підвищенням умовної частки кровності за голштинською породою.

Збільшення умовної частки кровності поліпшувальної породи до 87,49 \% у генотипі первісток української червонорябої молочної породи та до 75,0% - корів вищої лактації, супроводжувалося підвищенням їх надою, але у подальшому виявлена зворотна тенденція зменшення надою корів за підвищення кровності.

У корів української чорно-рябої молочної породи з підвищенням спадковості голштинської породи до 75,0 \% за поліпшувальною породою встановлено вищу молочну продуктивність першої і вищої лактації.

При розведенні тварин відповідної породи слід обірунтовувати доцільність відтворювального схрещування і зосередитися на одержанні потомства з бажаною умовною часткою кровності за поліпшувальною породою.

\section{Список використаної літератури:}

1.Болгова Н.В. Вплив генотипових чинників на молочну продуктивність корів. Збірник наукових праць Вінницького національного аграрного університету. Вінниця, 2011. Вип.8 (48). С.7-11.

2.Боровиков B. STATISTICA. Искусство анализа данных на компьютере: для профессионалов. Санкт-Петербург, $2001.56 \mathrm{c}$.

З.Буркат В.П., Мельник Ю.Ф., Єфріменко М.Я., Полупан Ю.П., Кругляк А.П. Програми селекції порід. Розведення і генетика тварин. Київ, 2003. Вип. 37. С. 3-22.

4.Войтенко С.Л., Сидоренко О.В., Вишневський Л.В. Селекційні досягнення у тваринництві України та видатні учені кінця XX початку XXI сторіччя. Полтава, 2019. 78c

5.Ефименко М.Я., Полупан Ю.П. Рекорды молочной продуктивности коров. Зоотехния. 1997. № 6. С. 9-10.

6. Зубець М.В., Буркат В.П. Основні концептуальні засади новітньої вітчизняної теорії породоутворення. Розведення $і$ генетика тварин. Київ, 2002. Вип. 36. С. 3-10.

7. Кот М.М., Хороших В.Т., Черкасов А.А. Что нужно знать при разведении голштинизированного чёрно-пёстрого скота. Зоотехния. 1991. №10. С.2-5.

8.Крыканова Л.Н. Голштино-фрризский скот США и Канады. Сельское хозяйство за рубежом. 1981. № 7. С43-49.

9.Меркурьева Е.К. Генетические основы селекции в скотоводстве. Москва, 1977. 240 с.

10.Микитюк Д.М., Литовченко А.М., Буркат В.П. та ін. Програма селекції української червоної молочної породи великої рогатої худоби на 2003-2012 роки. Київ, 2004. 216 с.

11.Милостивый Р. В., Карлова Л. В. Продуктивное долголетие голштинских коров европейской селекции разных линий в условиях промышленной технологии. Розведення і генетика тварин . Київ, 2003. Вип. 54. С. 65-73.

12.Мельник Ю. Ф., Литовченко А. М., Білоус О.В. та ін. Програма селекції української червоно-рябої молочної породи великої рогатої худоби на 2003-2012 роки. Київ, 2003. 77 с.

13. Мельник Ю.Ф., Микитюк Д.М., Пищолка В.А. та ін. Програма селекції української чорно-рябої молочної породи великої рогатої худоби на 2003-2012 роки. Київ, 2003. 83 с.

14. Охапкин С. Современное понятие о породе и породообразовании. Молочное и мясное скотоводство. 2000. № 1.

15.Паронян И.А., Юрченко О.П., Филипова Н.Д., Смирнов А.С. Сохранение и рациональное использование генофонда отечественных пород. Зоотехния. 2000. № 8. С. 25-27.

16.Піддубна Л. Вплив генотипових та паратипових факторів на молочну продуктивність української червоно-рябої молочної худоби. Тваринництво України. 2014. № 3-4. С. 11-14.

17.Сакса Е.И. Роль целенаправленного отбора и подбора при создании высокопродуткивных голштинизированных стад чёрно-пёстрого скота. Генетика и разведение животных. 2014. № 2. С.7-10.

18.Салогуб А.М. Молочна продуктивність корів залежно від умовної частки спадковості поліпшуючої породи. Вісник Сумського національного аграрного університету. Суми, 2009. Вип. 10 (16). С. 88-93.

19.Хмельничий Л.М., Вечорка В.В. Генотипові та паратипові чинники впливу на ознаки молочної продуктивності корів української чорно-рябої молочної породи. Вісник Сумського національного аграрного університету. 2014. Вип. 7 (26). С. 87-90.

20.Хмельничий Л.М., Ладика В.І., Салогуб А.М. Методологічний аспект створення молочних корів бажаного типу. Проблеми зооінженерії та ветеринарної медицини. Харків, 2009. Вип. 18. Ч. 1. С. 307-311.

21. Хмельничий Л.М., Салогуб А.М., Жмурко С.М., Корнієнко Т.І., Котов Б.В., Сіряченко О.О., Соколов А.Ю. Генотипові та паратипові чинники впливу на ознаки молочної продуктивності корів молочних порід сумського регіону. Вісник Сумського національного аграрного університету. Суми, 2011. Вип.7 (19). С.25-29.

22.Шарганов В.М. Історія та сучасні тенденції у скотарстві Канади. Вісник Сумського національного аграрного університету. Суми, 2008. Вип.10 (15). С.134-138.

23.Янчуков И., Матвеева Е., Лаврухина А. Горизонты в селекции молочного скота. Молочное и мясное скотоводство. 2011. №1. C.10-11.

24.Bratherstone S. Genetics and phenotypic correlations between linear type traits and production traits in holstain-friesian drairy cattle. Anim. Prod. 1994. V. 59. P.183-187.

25.The influence of additive and nonadditive gene action on lifetime yields and profitability of dairy cattle. McAllister A. J., Lee A. J., Batra T. R. et.al. J. Dairy Sci. 1994. V.77. №8. P.2400-2414 


\section{References:}

1. Bolhova, N.V., 2011. Vplyv henotypovykh chynnykiv na molochnu produktyvnist koriv [Influence of genotypic factors on dairy productivity of cows]. Zbirnyk naukovykh prats Vinnytskoho natsionalnoho ahrarnoho universytetu, issue 8(48), pp. 7-11.

2.Borovikov, V., 2001. STATISTICA. Isskustvo analiza dannykh na komp'yutere: dlya professionalov [STATISTICS: Art of computer data analysis: for professionals]. S.-Peterburg.

3. Burkat, V.P., Melnyk, Yu.F., Yefimenko, M.la., Polupan, Yu.P. and Kruhliak, A.P., 2003. Prohramy selektsii porid [Breed breeding programs]. Rozvedennia i henetyka tvaryn, issue 37, pp. 3-22.

4.Voitenko, S.L., Sydorenko, O.V. and Vyshnevskyi, L.V., 2019. Selektsiini dosiahnennia u tvarynnytstvi Ukrainy ta vydatni ucheni kintsia XX pochatku XXI storichchia [Breeding achievements in animal husbandry of Ukraine and outstanding scientists of the end of $X X$ beginning of $X X I$ century]. Poltava.

5. Efimenko, M.Ya. and Polupan, Yu.P., 1997. Rekordyi molochnoy produktivnosti korov. [Cows milk production records]. Zootekhnyia, issue 6, pp. 9-10.

6. Zubets, M. V. and Burkat, V. P., 2002. Osnovni kontseptualni zasady novitnoi vitchyznianoi teorii porodoutvorennia [Basic conceptual foundations of the newest domestic theory of rock formation]. Rozvedennia $i$ henetyka tvaryn, issue 36, pp. 3-10.

7. Kot, M.M., Horoshih, V.T. and Cherkasov, A. A., 1991. Chto nuzhno znat pri razvedenii golshtinizirovannogo chYornopYostrogo skota [What you need to know when breeding Holstein black-motley cattle]. Zootekhnyia, issue 10, pp. 2-5.

8. Kryikanova, L.N., 1981. Golshtino-frizskiy skot SShA i Kanadyi [Holstein-Friesian cattle of the USA and Canada]. Selskoe khoziaistvo za rubezhom, issue 7, pp. 43-49.

9.Merkur'eva, E. K., 1977. Geneticheskie osnovy selektsii v skotovodstve [Genetic Principles of selective breeding in cattle breeding]. Kolos: Moskov.

10.Mykytiuk, D. M., Lytovchenko, A. M., Burkat, V. P. and in., 2004. Prohrama selektsii ukrainskoi chervonoi molochnoi porody velykoi rohatoi khudoby na 2003-2012 roky [The program of selection of Ukrainian Ukrainian dairy breed of great horny skin for 2003-2012 rock]. Kyiv.

11.Milostivyiy, R.V., Karlova, L.V., 2003. Produktivnoe dolgoletie golshtinskih korov evropeyskoy selektsii raznyih liniy v usloviyah promyishlennoy tehnologii [Productive longevity of Holstein cows of European selection of different lines in the conditions of industrial technology]. Rozvedennia i henetyka tvaryn, issue 54, pp. 65-73.

12.Melnyk, Yu. F., Lytovchenko, A. M., Bilous, O.V. and in., 2003. Prohrama selektsii ukrainskoi chervono-riaboi molochnoi porody velykoi rohatoi khudoby na 2003-2012 roky [Breeding program for the Ukrainian red-breasted cattle dairy breed for 2003 2012]. Kyiv.

13.Melnyk, Yu. F., Mykytiuk, D. M., Pyshcholka, V. A. and in., 2003. Prohrama selektsii ukrainskoi chorno-riaboi molochnoi porody velykoi rohatoi khudoby na 2003-2012 roky [Breeding program for the Ukrainian black and white dairy cattle breed for 20032012]. Kyiv.

14.Ohapkin, S., 2000. Sovremennoe ponyatie o porode i porodoobrazovanii [The modern concept of breed and breed formation]. Molochnoe i myasnoe skotovodstvo, issue 1, pp. 24-27.

15.Paronyan, I.A., Yurchenko, O.P., Filipova, N.D. and Smirnov, A.S., 2000. Sohranenie i ratsionalnoe ispolzovanie genofonda otechestvennyih porod [Conservation and rational use of the gene pool of domestic breeds]. Zootekhnyia, issue 8 , pp. 25-27.

16. Piddubna, L., 2014. Vplyv henotypovykh ta paratypovykh faktoriv na molochnu produktyvnist ukrainskoi chervono-riaboi molochnoi khudoby [Influence of genotype and paratype factors on dairy productivity of Ukrainian red-breasted dairy cattle]. Tvarynnytstvo Ukrainy, issue 3-4, pp. 11-14.

17. Saksa, E.I., 2014. Rol tselenapravlennogo otbora i podbora pri sozdanii vyisokoprodutkivnyih golshtinizirovannyih stad chYorno-pYostrogo skota [The role of targeted selection and selection in the creation of highly productive holsteinized herds of black-motley cattle]. Genetika i razvedenie jivotnyih., issue 2, pp.7-10.

18. Salohub, A. M., 2009. Molochna produktyvnist koriv zalezhno vid umovnoi chastky spadkovosti polipshuiuchoi porody [Dairy performance of cows, depending on the contingent proportion of hereditary breed improvement]. Visnyk Sumskoho natsionalnoho ahrarnoho universytetu, issue 10 (16), pp. 88-93.

19. Khmelnychyi, L. M. and Vechorka, V.V., 2014. Henotypovi ta paratypovi chynnyky vplyvu na oznaky molochnoi produktyvnosti koriv ukrainskoi chorno-riaboi molochnoi porody [Genotypic and paratypical factors influencing the characteristics of dairy productivity of cows of Ukrainian black-rumped dairy breed]. Visnyk Sumskoho natsionalnoho ahrarnoho universytetu, issue 7 (26), pp. 87-90.

20. Khmelnychyi, L. M., Ladyka, V. I. and Salohub, A. M., 2009. Metodolohichnyi aspekt stvorennia molochnykh koriv bazhanoho typu [Methodological aspect of creation of dairy cows of the desired type]. Problemy zooinzhenerii ta veterynarnoi medytsyny, issue 18, part 1, pp. 307-311.

21. Khmelnychyi, L.M., Salohub, A.M., Zhmurko, S.M., Korniienko, T.I., Kotov, B.V., Siriachenko O.O. and Sokolov, A.lu., 2011. Henotypovi ta paratypovi chynnyky vplyvu na oznaky molochnoi produktyvnosti koriv molochnykh porid sumskoho rehionu [Genotypic and paratypical factors influencing the milk production characteristics of dairy cows of Sumy region]. Bulletin of Sumy National Agrarian University, issue 7 (19), pp. 25-29.

22.Sharhanov, V.M., 2008. Istoriia ta suchasni tendentsii u skotarstvi Kanady [History and current trends in cattle breeding in Canada]. Visnyk Sumskoho natsionalnoho ahrarnoho universytetu, issue 10 (15), pp. 134-138.

23. Yanchukov, I., Matveeva, E. and Lavruhina, A., 2011. Gorizontyi v selektsii molochnogo skota [Horizons in Dairy Cattle Breeding]. Molochnoe i myasnoe skotovodstvo, issue 1, pp.10-11. 
24.Bratherstone, S., 1994. Genetics and phenotypic correlations between linear type traits and production traits in holstainfriesian drairy cattle. Animal Production, vol. 59, pp. 183-187.

25.McAllister, A.J., Lee, A.J., Batra, T.R. et. al., 1994. The influence of additive and nonadditive gene action on lifetime yields and profitability of dairy cattle. J. Dairy Sci, vol. 77, issue 8, pp. 2400-2414.

\section{Voitenko S. L,}

Sydorenko O.V.

The impact of improving breed on dairy productivity of cows of different breeds of domestic selection.

Breeding of cattle of dairy productivity in Ukraine in recent years is carried out with the intensive use of reproductive breeding, where the parent breed is Holstein, which leads to the appearance in the herd or breed of individuals with a huge diversity of genotypes with heterogeneous productivity. For the consolidation of cattle of Ukrainian dairy breeds for economically useful features, it is necessary to set the maximum permissible limits of the conditional stiffness of the Holstein breed in the genotype of animals of newly created breeds. The purpose of the research was to determine the milk productivity of cows of different breeds of breeding herds of the experimental farms of the NAAS, depending on the conditional share of blood in their genotype of the Holstein breed. The studies were conducted in herds of research farms of the NAAS according to the data of breeding records of cows of Ukrainian Black-and-White Dairy (2130 heads), Ukrainian Red-and-White Dairy breeds (689 heads) and Ukrainian Red Dairy (176 heads). Significant differentiation of milk yields of cows of different breeds has been established depending on the proportion of conditioned blood supply by the Holstein breed. The possibility of even increase of milk productivity of cows of Ukrainian Red Dairy of the first and higher lactation with increase of a share of blood count on Holstein breed is proved. For cows of the Ukrainian Red-and-White dairy breed, the upper limit of conditional blood yield for the Holstein breed, which contributed to the increase in milk yield of the first lactation was $87.49 \%$, and for the higher lactation - 75.0\%. Animals of the Ukrainian Black-and-White Dairy breed have a higher hope of first and higher lactation with an increase in their genotype of the conditional share of blood by the breed of improvement to $75.0 \%$. An increase in the proportion of conditional blood over Holstein breeds beyond the specified limits leads to a decrease in dairy productivity of cows. In general, the further breeding of cattle of Ukrainian dairy breeds requires a clear justification for the use of Holstein breed for reproductive breeding, taking into account the results of the effect of conditional blood on the milk productivity of cows.

Key words: cattle, milk productivity, lactation, conditional blood, improving breed.

Дата надходження до редакції: 14.09.2019 р. 